\title{
Predictability of Stock Returns Using Financial Ratios: Empirical Evidence from Colombo Stock Exchange
}

\author{
A. A. V. I. Wijesundera, D. A. S. Weerasinghe, T. P. C. R. Krishna, \\ M. M. D. Gunawardena* and H. R. I. Peiris \\ Faculty of Business, Sri Lanka Institute of Information Technology, Sri Lanka \\ *maliendra.d@sliit.lk
}

\begin{abstract}
The purpose of this research is to examine the ability of the historical financial information in constructing a resilient value portfolio for investors by predicting stock returns in the Sri Lankan context. One of the most imperative and interesting phenomena for the investors and the analysts would be the stock returns from the financial markets. The present study will aim at mainly to assess correlation between financial ratios and the predictability of stock returns for companies listed on the Colombo Stock Exchange. This study applies ordinary least squares (OLS) techniques to estimate the predictive regressions in form of simple and multiple models of panel data sets. For the current study, 60 listed companies were selected and 10 years of data has been analyzed from 2004 to 2013. The results highlighted that ROE, EPS and MV/BV have a significant positive relationship with the stock return which is followed by a simple equation to predict the future stock returns. Hence the investors should consider these ratios of the companies and movement in these ratios in selecting a resilient portfolio to invest.
\end{abstract}

Keywords: Financial ratios, Stock Return, Colombo Stock Exchange

\section{Introduction}

Stock market plays a substantial role in the economic growth of a country. Economic growth of each country is influenced by the money and capital markets in the economy of each country. Horrigan (1995) has stated that the most significant source that can give discernibility to investors about the company is the financial statement and the ratios that play a significant role in the market over five years or more. However as per the Sri Lankan context valuation multiples and macro-economic factors such as impact of economic factors, political stability, attractiveness of the industry, company's position in the industry are well related factors which affect the stock returns. Today the prediction of stock returns has been very important from the investor's point of view. This empirical study specifically identifies financial ratios, which are known as the predictors of stock returns in the share market, to test the stock return predictability on the Sri Lankan market. The financial ratios include the Dividend yield, Price to earnings ratio $[\mathrm{P} / \mathrm{E}$ ratio], The ratio of book value to market value $[\mathrm{B} / \mathrm{M}]$, Return on equity, Earnings per share, Earnings Yield which are most useful and effective on stock return predictability in order to cover a wide range of predictions which have been used by all most all the previous researches. Investors seek those financial measures like financial ratio analysis that have significant impact on deciding the winning portfolio. 
In our research it has been observed that it is difficult to predict stock returns solely based on the historical financial information because stock prices evolve. Therefore foretelling $100 \%$ accuracy is impossible. With the road of time our intention is to find out most accurate variables for predicting stock returns in Sri Lanka. We have investigated above five investor and profitability ratios to determine whether they predict stock returns and on the grounds of their applicable regression models. Statistically there is a significant relationship between stock return and ROE, EPS and MV/BV which gained ninety five percent of confidence level. However it's probable that majority of the investors in Sri Lankan stock market are followed by speculation and other macro-economic factors such as political stability, attractiveness of the industry, economic factors etc.

\section{Literature Review}

Basu (1977) in a time period from April 1957 to March 1971 showed that in addition to the size of the company and the stock's beta, price to earnings ratio also plays a great role in explaining average returns. He observed those stocks with a high ratio of profit to sales have significantly higher returns than stocks with low ratio of profit to sales and changes in Beta cannot explain stock return changes so that even after controlling Beta, stocks with a lower ratio of profit to sales have higher returns than stocks with a high ratio of profit to sales.

James Horrigan (1995) in his research has proved through an empirical study that ratios and factors play a significant role in the market over 5 years or more. He also cites the use of Price Earnings Ratio (PE Ratio) and Earnings per Share (EPS) as indicator ratios. He states that there was a trend in the early 60's, which was an increase in EPS providing a proper reasoning for the bullish market which existed at that time.

It has also been proved that the dividend yield has the ability to confine expected return and expectation about growth in dividend yield so dividend yield is a good predictor of stock return (Campbell \& Shiller, 1988).

It has been found that in Japanese market fundamental variables like dividend yield, price to earnings ratio, book to market ratio and firm's size have significant impact on expected earning/returns of stocks (Chan, et al., 1991).

Kothari \& Shanken (1997) in their research found out for the US market where Dividend yield and ratio of book value to market value $[\mathrm{B} / \mathrm{M}]$, have an association to the expected real return over a period of 65years (1926-1991).

Examination of the association between financial ratios and stock returns for 50 industrial firms traded in the French stock market confirms that the financial statement information helps in predicting stock returns. (Martinez, 1999). Nissim \& Penman 
(2001) provide rigorous evidence on the utility of the accounting ratios in projecting future streams of abnormal earnings.

A study done by Hjalmarsson (2004) focused on predicting the Global stock returns. The study was to analyze 20,000 monthly observations form forty international stock markets. And showed that dividend yield and price to earnings ratio has little power of predictability. Liolen (2004) examined the predictability of stock returns using financial ratios including dividend yield, the book value to the market value, and profit to sales. He found that dividend yield has more power to predict stock returns than other variables.

Christos, et al., (2005) examined the use of financial ratios to predict stock returns through linear regression and the Garch Test in the Greek Stock Exchange. The comparative results of time series models and the Garch testing models indicated that the ECM-GARCH Technique shows the correlations between variables more effectively. Kheradyar (2011) conducted a study in the Malaysian stock exchange which revealed the predictive power of Book Value to Market value is higher than other ratios. According to A. Schrimpf (2010) there is significant economic repercussion of the existence of stock return predictability. Kheradyar et al, (2011), "The Analytics of Economic Time Series", states that in stocks market share prices move randomly. However, investors are not necessarily concerned with a company's financial situation unless they can profit from it. Therefore, investors rely on ratios that show a company can provide them with future returns. Historically, the most important of these are earnings per share and the dividend payout ratio. Lewellan, (2004) himself, hypothesizes that other factors aside from traditional financial ratios, such as integrity and ethical values affect stock price. However, his study shows that even in an economy plagued by scandal, financial ratios are still good indicators of what a company's stock price will be in the future.

Taani and Banykhaled (2011) discovered that there is a positive and significant relationship in between market value, debt ratio, operating cash flows and return on equity with earnings per share following a study on the effect of ratios, firm size and cash flow from operating activities on EPS. However a relationship between firm size and EPS was not observed.

The previous researches that have been gathered were able to cater instincts to decide a pipeline for this research to analyze the gap which is specifically involved with the stock market in Sri Lanka and assisted the researches to decide crucial factors which is to be incorporated into the analysis. 


\section{Methodology}

The study was conducted over a ten year period from early 2004 to 2013. In this case, 'Stratified sampling' method has been utilized where the researchers' have formed strata based on shared attributes in selection of companies, which consider as the representation of the population. For the current study, 60 listed companies will be selected out of 298 listed companies in Colombo Stock Exchange in which 10 years data were analyzed. Certain screening criteria's were applied for companies to be selected as the sample. First the company must be listed on the Colombo stock exchange before $1^{\text {st }}$ January 2003 . Second the company stock must not be delisted during the period of study. Third, the data must be available for all sample firms and variables. Fourth, the top 60 companies will be selected based on their market capitalization.

The most relevant five ratios have been selected from the entire pool of investor ratios by judgment as the independent variables. Simultaneous descriptive statistical analyses have been utilized since it helps to analyze all kinds of accounting information.

\section{Measurement of Variables}

In this study, stock returns $\left(\mathrm{SR}_{\mathrm{it}}\right)$ in the companies listed on the Colombo Stock Exchange are selected as the dependent variable. Where, $\mathrm{SR}_{\mathrm{it}}$ is the return on ordinary stock during the period $\mathrm{t}$.

\subsection{Stock Returns}

This research has used stock return as dependent variable. Stock return is measured by adding capital gain along with dividend per share. Following is the formula for stock returns.

$$
\mathrm{SR}_{\mathrm{it}}=D P s+\text { capital gain }
$$

The independent variables include Dividend yield, Price to earnings ratio [P/E ratio], the ratio of book value to market value $[\mathrm{B} / \mathrm{M}]$, Return on equity, Earnings per share. The relationship between Dividend yield ratio, Price to earnings ratio [P/E ratio], Return on equity, Earnings per share and the ratio of book value to market value $[\mathrm{B} / \mathrm{M}]$ to stock returns in the Colombo Stock Exchange is observed in the present study.

\subsection{Return on Equity}

Return on equity is obtained by dividing net income by the equity shares. It measures the rate of return on the shareholders' equity of the common stock owners. ROE demonstrates how well a company utilizes investment funds to generate earnings growth. It basically involves in measuring the efficiency at making profits from net assets (Shareholders' equity). 


\subsection{Ratio of Book Value to Market Value}

The ratio of book value to market value is derived by dividing market price per share by the book value per share. A ratio applied to discover the value of a company by comparing the book value of a company to its market price. Book value is figured out by considering the company's historical cost, or accounting value. Market value is discovered in the stock market from its market capitalization. This indicates the market price per share in terms of the book value of equity. A price to Book Value ratio of lower than the industry average will reflect that the company's management and the performance of the company might have some problems or a good company with less investor attention.

\subsection{Earnings per Share}

Earnings per share is obtained by the dividing the profit after preference dividend by the weighted average common shares. EPS is the monetary value of each earnings per each share which is outstanding. It serves as an indicator of the profitability of the company. It is regarded as the single most vital variable in determining a share price.

Table 01 summarize the mean, median, maximum, minimum, and the standard deviation of the variables under study.

Table 01: Descriptive Statistics of the Variables

\begin{tabular}{lrrrrrr}
\hline & \multicolumn{5}{c}{ Dependent Variable } & \multicolumn{5}{c}{ Independent Variables } \\
\cline { 2 - 7 } & $\boldsymbol{S R}$ & $\boldsymbol{P E}$ & $\boldsymbol{R} \boldsymbol{O E}$ & $\boldsymbol{E P S}$ & $\boldsymbol{D Y}$ & $\boldsymbol{M V} \boldsymbol{B} \boldsymbol{V}$ \\
\cline { 2 - 7 } Mean & 28.18 & 21.99 & 0.13 & 13.17 & 0.03 & 2.35 \\
Median & 4.48 & 9.81 & 0.10 & 5.12 & 0.03 & 1.50 \\
Maximum & 1605.00 & 1902.14 & 1.65 & 325.76 & 0.53 & 38.78 \\
Minimum & -520.30 & 0.00 & -1.11 & -46.36 & 0.00 & -100.00 \\
Std. Dev. & 135.80 & 93.94 & 0.20 & 29.39 & 0.04 & 5.73 \\
\hline
\end{tabular}

Note: SR,PE,ROE,EPS,DY and MV/BV are respectively Stock Return, Price to Earning, Return on Equity, Earnings per Share, Book to Market Value

\section{Research Hypotheses}

The main objective of this research was to examine the predictability of stock returns in the Colombo Stock Exchange using financial ratios. In order to achieve the objective of this study the following hypotheses were formulated. 
$\mathbf{H}_{1}$ : There is a considerable association between stock returns and price-toearnings ratio in the listed companies in the Colombo Stock Exchange;

$\mathbf{H}_{2}$ : $\quad$ There is a considerable association between stock returns and return on equity in the listed companies in the Colombo Stock Exchange.

$\mathbf{H}_{3}$ : There is a considerable association between stock returns and earnings per share in the listed companies in the Colombo Stock Exchange.

$\mathbf{H}_{4}$ : There is a considerable association between stock returns and dividend yield in the listed companies in the Colombo Stock Exchange.

H5: There is a considerable association between stock returns and the ratio of the book value to the market value in the listed companies in the Colombo Stock Exchange;

$\mathbf{H}_{6}$ : There is a considerable association between stock return and combination of $\mathrm{PE}, \mathrm{BV} / \mathrm{MV}$, ROE, EPS, and DY in the listed companies in the Colombo Stock Exchange.

\section{Techniques of Data Analysis}

This research used panel data analysis technique which is often considered to be an efficient analytical method in handling econometric data. Hence, this research utilized the panel data regression techniques. Indeed by looking at the nature of the data collected, which are cross sectional and time series, is compatible with this technique, as the cross-sectional data reflected in stock returns and ratios of different companies and the time series reflected the in the changes within stock return and ratios over time in each company. Hausman specification test applied to recognize the appropriate method for data analysis. The results of Hausman test indicate the random effect method is more appropriate for the data analysis.

This study applied ordinary least square method (OLS) to correct set of covariance and t-statistics. When data are ordered in chronological order, the error on one time period may affect the error on next time periods, so this study employs the Durbin-Watson (DW) test for recognizing the autocorrelation. The results of DW test shown in table III indicate no serial correlation in all applied regressions because of the DW test statistic amount to 2.05 .

This research used panel data models to formulate predictive regressions. Hence it have used simple regression model to test the first 5 hypothesis which are formulated on the basis of association between each financial ratio and future stock returns. This research examined 6 hypotheses by the predictive regression models in the panel data set. This research have used simple predictive regression model to test first five hypotheses under study. 
The simple regression model has the following form:

$$
\text { SRit }=\beta 0+\beta \text { i Xi (t-1) }+ \text { cit }
$$

\section{Where:}

SRit= in time period $\mathrm{t}$, the return of $\mathrm{i}^{\mathrm{th}}$ stock,

$\beta 0=$ the estimated constant,

$\beta \mathrm{i}=\mathrm{i}^{\text {th }}$ stock predictable coefficient,

$\mathrm{Xi}(\mathrm{t}-1)=$ in period $\mathrm{t}-1$ financial ratios of the $\mathrm{i}^{\text {th }}$ stock, $\varepsilon i t=$ error term.

Furthermore, the comparison between the results of simple and multiple predictive regression models indicate that the predictive power of financial ratios are increased when the ratios are combined in the multiple regression model. One possible explanation of the increase in the predictive power of financial ratios of the multiple regression models is that the roles of each financial ratio are unique and complementary because each financial ratio provides specific information, which is used by investors on stock return predictability.

Following S. Kheradyar et al, (2011) we have used multiple regression model to test the relationship between combined financial ratios and future stock returns. Subsequently we applied the multiple predictive regression model for testing hypothesis 6 which includes the combination of individual financial ratios to find how the combined ratios can be used to predict the stock return.

The model has the following form:

$$
\mathrm{SR}_{\mathrm{it}}=\beta_{0}+\beta_{\mathrm{i} 1} \mathrm{PE}_{\mathrm{i}(\mathrm{t}-1)}+\beta_{\mathrm{i} 2} \mathrm{ROE}_{\mathrm{i}(\mathrm{t}-1)}+\beta_{\mathrm{i} 3} \mathrm{EPS}_{\mathrm{i}(\mathrm{t}-1)}+\beta_{\mathrm{i} 4} \mathrm{DY} \mathrm{i}_{\mathrm{i}(\mathrm{t}-1)}+\beta_{\mathrm{i} 5} \mathrm{M} / \mathrm{B}_{\mathrm{i}(\mathrm{t}-1)}+\varepsilon \mathrm{it}
$$

\section{Where:}

$\mathrm{SR}_{\mathrm{it}}=$ in time period $\mathrm{t}$, the return of $\mathrm{i}^{\mathrm{th}}$ stock,

$\beta_{0}=$ the estimated constant,

$\beta_{\mathrm{i} 1}=$ for PE the $\mathrm{i}^{\mathrm{th}}$ stock predictable coefficient,

$\beta_{\mathrm{i} 2}=$ for ROE the $\mathrm{i}^{\text {th }}$ stock predictable coefficient,

$\beta_{\mathrm{i} 3}=$ for EPS the $\mathrm{i}^{\text {th }}$ stock predictable coefficient,

$\beta_{\mathrm{i} 4}=$ for DY the $\mathrm{i}^{\text {th }}$ stock predictable coefficient,

$\beta_{i s}=$ for $M / B$ the $i^{\text {th }}$ stock predictable coefficient,

$P E_{i(t-1)}=$ is $i^{\text {th }}$ stock PE factor in period of time $\mathrm{t}-1$,

$\mathrm{ROE}_{\mathrm{i}(\mathrm{t}-1)}=\mathrm{ROE}$ factor of $\mathrm{i}^{\text {th }}$ stock in period of time $\mathrm{t}-1$,

$\mathrm{EPS}_{\mathrm{i}(\mathrm{t}-1)}=\mathrm{EPS}$ factor of $\mathrm{i}^{\text {th }}$ stock in $\mathrm{t}-1$ time period,

$D Y_{i(t-1)}=D Y$ factor of $i^{\text {th }}$ stock in $\mathrm{t}-1$ time period

$M / B_{i(t-1)}=M / B$ factor of $i^{\text {th }}$ stock in $t-1$ time period

$\varepsilon i t=$ error terms. 


\section{Results and Discussion}

This research examined the six hypothesis using predictive regression models in the panel data set. Simple predictive regression model was applied in testing the first five hypotheses which the results are summarized in table 2 .

Table 02: The Simple Predictive Regression Results

\begin{tabular}{|c|c|c|c|c|}
\hline & $\beta 0$ & $\beta i$ & $R^{2}$ & p-value \\
\hline Model PE & \multicolumn{4}{|c|}{ Rit $=\beta 0+\beta \mathrm{i} \operatorname{PEi}(\mathrm{t}-1)+\varepsilon$ it } \\
\hline Sample & 27.92 & 0.0118 & 0.00 & 0.8427 \\
\hline Model ROE & \multicolumn{4}{|c|}{ Rit $=\beta 0+\beta$ ROEi $(t-1)+\varepsilon i t$} \\
\hline Sample & 15.10 & 101.3890 & 0.02 & 0.0010 \\
\hline Model EPS & \multicolumn{4}{|c|}{ Rit $=\beta 0+\beta \mathrm{i} \operatorname{EPSi}(\mathrm{t}-1)+\varepsilon$ it } \\
\hline Sample & 9.94 & 1.3845 & 0.09 & 0.0000 \\
\hline Model DY & \multicolumn{4}{|c|}{ Rit $=\beta 0+\beta i \mathrm{DYi}(\mathrm{t}-1)+\varepsilon i \mathrm{t}$} \\
\hline Sample & 34.13 & -177.93 & 0.00 & 0.1929 \\
\hline Model MV/BV & \multicolumn{4}{|c|}{ Rit $=\beta 0+\beta \mathrm{i} \mathrm{MV} / \mathrm{BVi}(\mathrm{t}-1)+\varepsilon i \mathrm{t}$} \\
\hline Sample & 21.11 & 3.0136 & 0.02 & 0.0022 \\
\hline
\end{tabular}

Note I: SR, PE, ROE, EPS, DY and MV/BV are respectively Stock Return, Price to Earning, Return on Equity, Earnings per Share, and Book to Market Value.

Note II: $\beta 0$ is unsystematic predictable constant component or the estimated constant, $\beta \mathrm{i}$ is the predictable coefficient of the $i^{\text {th }}$ stock, sit is unsystematic error from the predicted Rit terms, $\mathrm{i}=1,2,3, \ldots, \mathrm{n}$.

Next researchers applied the multiple regression model to come up with a multiple predictive model in predicting stock returns. H6 hypothesis was stated to test the predictive ability of the financial ratios by applying the predictive regression model. Random effect of the panel data method is used as for the Hausman test results. Table III shows the summarized regression model result for the H6. Based on the results $\mathrm{R}^{2}$ of the multiple regression analysis is 0.1170 . This shows that by combining the financial ratios it will lead to increase the predictive power of stock return using financial ratios.

As for the results obtained by applying simple predictive regression model three alternative hypotheses which $\mathrm{H} 2, \mathrm{H} 3$ and $\mathrm{H} 5$ was accepted at 95\% of confidence level. So statistically there is a significant relationship between stock return and ROE, EPS and MV/BV. As for the results of statistical analysis $\mathrm{H} 1$ and $\mathrm{H} 4$ hypotheses were rejected. Based on the statistical analysis ROE has a coefficient of 101.38 which is significant since the $\mathrm{p}$ value is 0.0010 which is lower than the 0.05 with $95 \%$ confidence 
level. So the $\mathrm{H} 1$ alternative hypotheses can be accepted concluding there is a significant relationship among stock return and ROE. EPS shows a coefficient of 1.3845 which the $\mathrm{p}$ value is 0.0000 which indicates that there is a significant positive relationship between stock return and EPS. H3 alternative hypothesis is accepted based on this. MV/BV shows a significant positive relationship towards the stock return as for the regression results. It gives a coefficient of 3.0136 with a p value of 0.0022 . With this result the $\mathrm{H} 5$ alternative hypothesis is accepted that there is a considerable association between stock return and the MV/BV. DY shows significant negative coefficient of 177.93 with a $\mathrm{p}$ value of 0.1929. In 2011 S.Kheradyar et al, also found that DY has negative influence on stock return in there research study. By looking at the R-square value of each independent variable EPS shows the highest value which is 0.09. Even though statistically EPS shows a strong positive relationship with stock return only 9 percent of the dependent variable is explained by the EPS because the $\boldsymbol{R}^{2}$ value is in table 02 is 0.09 . Table 02 indicates the results generated by simple predictive regression analysis.

\section{Table 03: The Multiple Predictive Regression Results}

\begin{tabular}{|c|c|c|c|c|c|c|c|}
\hline \multicolumn{8}{|c|}{$\begin{array}{c}\text { Rit }=\beta 0+\beta i 1 \text { PEi(t-1) }+\beta i 2 \operatorname{ROEi}(t-1)+\beta i 3 \text { EPSi }(t-1)+\beta i 4 \text { DYi(t-1) }+\beta i 5 \\
\text { MV/BVi(t-1) }+ \text { eit }\end{array}$} \\
\hline$\beta 0$ & $\beta \mathrm{i} 1$ & $\beta \mathrm{i} 2$ & $\beta \mathrm{i} 3$ & $\beta \mathrm{i} 4$ & $\beta \mathrm{i} 5$ & $\mathrm{R}^{2}$ & DW \\
\hline 4.88 & -0.0050 & 76.74 & 1.28 & -282.65 & 2.62 & 0.1170 & 2.04 \\
\hline
\end{tabular}

Note I: SR, PE, ROE, EPS, DY and MV/BV are respectively Stock Return, Price to Earning, Return on Equity, Earnings per Share, and Book to Market Value.

Note II: $\beta 0$ is unsystematic predictable constant component or the estimated constant, $\beta \mathrm{i} 1$, $\beta \mathrm{i} 2, \beta \mathrm{i} 3, \beta \mathrm{i} 4$ and $\beta \mathrm{i} 5$ are respectively the predictable coefficient of the PE, ROE, EPS, DY and $\mathrm{M} / \mathrm{B}$ factors of the $\mathrm{i}^{\text {th }}$ stock, $\mathrm{i}=1,2,3, \ldots, \mathrm{n}$.

Note III: DW is Durbin-Watson test for recognizing the autocorrelation as the figures indicates that there is no serial correlation in all applied regressions because of the DW test statistic is very close to 2 .

In order to find the most appropriate model which can be used in predicting stock return was derived as follows. Table IV shows the multiple regression analysis summaries of ROE, EPS and MV/BV. As a result ROE, EPS and MV/BV can predict the future stock returns stronger than each of them lonely. 
Table 04: The Multiple Predictive Regression Results with combination of EPS and $M / B$

\begin{tabular}{|c|c|c|c|c|c|}
\hline \multicolumn{6}{|c|}{ Rit $=\beta 0+\beta i 2 \operatorname{ROEi}(t-1)+\beta i 3 \operatorname{EPSi}(t-1)+\beta i 5 \mathrm{MV} / \mathrm{BVi}(\mathrm{t}-1)+$ eit } \\
\hline$\beta 0$ & $\beta \mathrm{i} 2$ & $\beta \mathrm{i} 3$ & $\beta \mathrm{i} 5$ & $\mathrm{R}^{2}$ & DW \\
\hline-1.91 & 51.1456 & 1.30 & 2.7166 & 0.1105 & 2.0511 \\
\hline
\end{tabular}

Note I: SR,ROE,EPS,MV/BV are respectively Stock Return, Return on Equity, Earnings per Share, Book to Market Value.

Note II: $\beta 0$ is unsystematic predictable constant component or the estimated constant, $\beta \mathrm{i} 2$, $\beta \mathrm{i} 3, \beta \mathrm{i} 5$ are respectively the predictable coefficient of the ROE,EPS,M/B factors of the $\mathrm{i}^{\text {th }}$ stock, $\mathrm{i}=1,2,3, \ldots, \mathrm{n}$.

Note III: DW is Durbin-Watson test for recognizing the autocorrelation as the figures indicates that there is no serial correlation in all applied regressions because of the DW test statistic is very close to 2 .

\section{Conclusion}

This paper examines the predictive power of five financial ratios on stock returns in Colombo Stock Exchange over ten years from 2004 to 2013. Many researches have attempted to discover the predictive power of the financial ratios on predicting the stock return. Most of the researches have concluded with different arguments over the period of time. Most of the researches were done on western countries and there were lack of researches on this area in south Asian counties, thus the predictive power of financial ratios in developing Asian countries is still unknown.

In this study the stock return predictability was measured using financial ratios. As for the results of regression analysis only ROE, EPS and MV/BV have a significant positive relationship with the stock return. Hence the investors should consider these ratios of the companies and movement in these ratios in selecting a resilient portfolio to invest. The focus on these ratios are understandable even for amateur investors who can easily calculated these ratios by relying on the information they obtain from Colombo Stock Exchange or related companies in order to make effective decision on selecting a resilient investment portfolio.

But the predictive power of each ratio shows a weak value when considering the RSquared value. In this case more researches need to be done by incorporating other factors such as beta factor, industry returns, interest rates, size of the firm and other nonnumerical factors such as economic factors, political stability, attractiveness of the industry, companies position in the industry in finding their impact on the stock return and find whether the stock return can be predicted in Sri Lankan stock market. 


\section{References}

Alexakis, C., Patra, T. \& Poshakwale, S., 2010. Predictability of stock returns using financial statement information: evidence on semi-strong efficiency of emerging Greek stock market. Applied Financial Economics, Volume 20, p. 1321-1326. http://dx.doi.org/10.1080/09603107.2010.482517

Ang, A. \& Bekaert, G., 2007. Stock Return Predictability: Is it there? The Review of Financial Studies, Volume 20, pp. 1-57. http://dx.doi.org/10.1093/rfs/hhl021

Anon., 2014. An Introduction to Colombo Stock Exchange. Colombo: Colombo Stock Exchange, Sri Lanka.

Banderlipe, M. R. S., 2006. Predicting Stock Returns Using Financial Ratios: Evidence from Selected Philippine Companies. pp. 1-45.

Bryman, A. \& Bell, E., 2008. Business research methods. 2nd Ed. New York: Oxford University Press Inc.

Cooper, M. J., Gulen, H. \& Schill, M. J., 2009. The Asset Growth Effect in Stock Returns. pp. $1-22$.

Dechow, P. M., Ak, B. K., Sun, E. Y. \& Wang, A. Y., 2013. Do Financial Ratio Models Help Investors Better Predict and Interpret Significant Corporate Events? pp. 1-74.

Hadassin, I., n.d. An Investigation into the Behavior of Earnings and Share Prices of South African Listed Companies.

Karami, G. R. \& Talaeei, L., 2013. Predictability of stock returns using financial ratios in the companies listed in Tehran Stock Exchange. International Research Journal of Applied and Basic Sciences, 4(12), pp. 4261-4273.

Khan, M. B. \& Gul, S., 2012. Financial Ratios and Stock Return Predictability (Evidence from Pakistan). pp. 1-6.

Kheradyar, S., Ibrahim, I. \& Nor, F. M., 2011. Stock Return Predictability with Financial Ratios. International Journal of Trade, Economics and Finance, 2(5), pp. 391-396.

Kim, J. H., Shamsuddin, A. \& Lim, K.-P., 2011. Stock return predictability and the adaptive markets hypothesis: Evidence from century-long U.S. data. Journal of Empirical Finance, Volume 18, pp. 868-879. http://dx.doi.org/10.1016/j.jempfin.2011.08.002

Kohansal, M. R., Dadrasmoghaddam, A., Karmozdi, K. M. \& Mohseni, A., 2013. Relationship between Financial Ratios and Stock Prices for the Food Industry Firms in Stock Exchange of Iran. World Applied Programming, 3(10), pp. 1-10.

Lettau, M. \& Nieuwerburgh, S. V., 2007. Reconciling the Return Predictability Evidence. The Review of Financial Studies, Volume 21, pp. 1-46.

Maio, P. \& Clara, P. S., 2012. Dividend yields, dividend growth, and return predictability in the cross-section of stocks. pp. 1-34. 
Menaje, P. M., 2012. Impact of Selected Financial Variables on Share Price of Publicly Listed Firms in the Philippines. American International Journal of Contemporary Research, 2(9), pp. 98-104.

Menaje, P. M., 2012. Impact of Selected Financial Variables on Share Price of Publicly Listed Firms in the Philippines. American International Journal of Contemporary Research, pp. 01-07.

Nezhad, S. H. S., Ramezani, A. \& Ebrahimpour, H., 2013. Investigation of the Market Reaction to Accounting Information Adjustments: Evidence from Tehran Stock Exchange. World of Sciences Journal, 1(12), pp. 165-175.

Pouraghajan, A. et al., 2013. Investigation the Effect of Financial Ratios, Operating Cash Flows and Firm Size on Earnings per Share: Evidence from the Tehran stock Exchange. pp. 01-08.

Rathnayaka, R., Nagahawatta, S. C. \& Seneviratna, D., 2014. Empirical Investigation of Stock Market Behavior in the Colombo Stock Exchange. Reshaping Management and Economic Thinking through Integrating Eco-Friendly and Ethical Practices, pp. 209210.

Regan, P. O., 2006. Financial information Analysis. 2nd Ed.

Salisu, A., n.d. Dividend Payout Ratio and Share Price Movement of Listed Non-Service Firms in Nigeria: Empirical Study. pp. 1-15. 
